\title{
Composition of free-living, aggregate-associated and sediment surface-associated bacterial communities in the German Wadden Sea
}

\author{
Heike Stevens, Thorsten Brinkhoff, Meinhard Simon* \\ Institute for Chemistry and Biology of the Marine Environment (ICBM), University of Oldenburg, \\ PO Box 2503, 26111 Oldenburg, Germany
}

\begin{abstract}
The Wadden Sea is a tidal flat ecosystem at the land-sea interface of the southern North Sea with a high load of suspended matter and nutrients. Despite the general importance of microbial processes, the composition of bacterial communities in this ecosystem has been little studied. Therefore, we investigated the composition of the bacterial communities freely suspended (FL) in the bulk water, associated with suspended aggregates (AG) and with the oxic sediment surface (SE) over an annual cycle (April 1999 to June 2000) in the East Frisian Wadden Sea, by applying denaturing gradient gel electrophoresis (DGGE) of PCR-amplified 16S rRNA gene fragments. Wind strength, suspended particulate matter (SPM), particulate organic carbon (POC), chlorophyll, phaeopigments, and the composition of the phytoplankton community were also studied. The dynamics of these parameters covaried to various extents, but not systematically, with that of bacterial numbers and community composition. A cluster analysis revealed that the DGGE banding patterns of the 3 communities grouped separately even though band overlaps among the communities occurred. Some identical or highly similar phylotypes were found in the FL- and AG-associated communities, and in the AG-and SE-associated communities, as shown by sequence analysis of excised bands. Prominent members of each community occurred over most of or during the entire study period. Dominant phylotypes in the FL-, AG- and SE-associated communities affiliated with $\alpha$-Proteobacteria (mainly Roseobacter clade) and $\gamma$-Proteobacteria. Phylotypes affiliating with $\delta$-Proteobacteria and Flavobacteria/Sphingobacteria of the Bacteroidetes phylum were detected occasionally in the AG- and SE-associated communities. During certain periods, 1 phylotype affiliating with Actinobacteria and 1 with $\beta$-Proteobacteria was detected in the FL-community. The prevalence of the rather stable composition of the communities over time, despite strong hydrodynamic forcing and pronounced seasonal changes in the phytoplankton community, SPM and POC, indicated that the bacterial communities were adapted to the environmental conditions in this highly dynamic system. The band overlaps between the various communities, however, also reflected that exchange processes between the dissolved and particulate phase and the sediment occurred.
\end{abstract}

KEY WORDS: Bacteria · Phytoplankton · Aggregates · POC · Sediment · DGGE · Wadden Sea Resale or republication not permitted without written consent of the publisher

\section{INTRODUCTION}

Tidal flats are one of the most productive coastal marine ecosystems and occur in tropical as well as temperate regions (Mauritania, Bangladesh, Australia, Korea, southern North Sea). The Wadden Sea is a tidal flat ecosystem with intense hydrodynamic forcing at the land-sea interface of the southern North Sea, highly affected by nutrient and organic matter input from land and the adjacent sea. The dynamics of nutrients, suspended matter, benthic and pelagic algal communities and primary production have been studied in various regions of the Wadden Sea (Admiraal et al. 1983, Van Leussen 1996, Behrends \& Liebezeit 1999, 
Niesel \& Günther 1999, Tillmann et al. 2000, Wolfstein et al. 2000). Bacterial production and turnover of organic matter have also been assessed, and studies have shown that the Wadden Sea is net-heterotrophic, emphasizing the significance of heterotrophic over autotrophic processes (Admiraal et al. 1985, Van Duyl \& Kop 1988, Poremba et al. 1999a). Because of the shallow, turbid and highly dynamic nature of the Wadden Sea, free-living as well as aggregate-associated bacteria and those associated with the oxic sediment surface layer are important in the aerobic decomposition of organic matter. Despite the extensive work on microbial processes carried out in the Wadden Sea, surprisingly little information is available on the composition of its bacterial communities. Böttcher et al. (2000) and Llobet-Brossa et al. (2002) examined the abundance of sulfate-reducing bacteria in sediments, but only Llobet-Brossa et al. (1998) studied the composition of sediment-associated bacterial communities in the Wadden Sea; their study was carried out in winter and showed that bacteria of the Cytophaga/ Flavobacteria cluster (now Flavobacteria/Sphingobacteria group of the Bacteroidetes phylum; Garrity et al. 2001) dominated during this season. No information, however, is available on the composition of free-living and aggregate-associated bacterial communities in the Wadden Sea.

The aim of our study was to investigate the composition of the free-living (FL), aggregate-associated (AG) and sediment surface-associated (SE) bacterial communities in the German Wadden Sea. We used denaturing gradient gel electrophoresis (DGGE) of PCRamplified 16S rRNA gene fragments, one of the most widely used approaches in this context (Muyzer et al. 1993). Banding patterns were subjected to a cluster analysis and selected bands were sequenced for subsequent phylogenetic analysis.

\section{MATERIALS AND METHODS}

Sampling site and sampling. Samples were collected monthly between April 1999 and June 2000 in the East Frisian Wadden Sea, Germany, at a site protected from westerly winds and currents by a groyne $\left(53^{\circ} 43^{\prime} 20^{\prime \prime} \mathrm{N}\right.$, 07 $43^{\prime} 20^{\prime \prime} \mathrm{E}_{\text {; }}$ Fig. 1). This site represents the bacterial community composition in the water column of this area, the tidal flat system of Spiekeroog Island, as shown by DGGE analyses of water samples of a horizontal survey (T. Brinkhoff \& H. P. Grossart unpubl. results). Sediment cores of the mixed sand/ mud flat were taken with Plexiglas tubes (36 mm diameter) at low tide. Water temperature, salinity, $\mathrm{pH}$ and oxygen saturation were measured in situ with probes LF 196, pH 192 and OXI 196 (all WTW), respectively. Wind data were obtained from the Deutscher Wetterdienst (German Meteorological Service), Hamburg. Water samples were collected at high tide using black $10 \mathrm{l}$ plastic jugs rinsed with seawater. For bacteria and phytoplankton cell counts, subsamples were withdrawn from the jugs immediately and fixed with $2 \%$ (bacteria) and $4 \%$ (algae) formalin. Samples were brought to the laboratory in a cooling box on ice and processed further. From the sediment core, the top $2 \mathrm{~mm}$ layer was sliced and transferred into a $2 \mathrm{ml}$ Eppendorf cap. To separate aggregate-associated and free-living bacteria, water samples were size-fractionated by serial filtration of 100 to $250 \mathrm{ml}$ through 5 and $0.2 \mu \mathrm{m}$ Nuclepore filters ( $47 \mathrm{~mm}$ diameter). Filters and sediment samples were stored and kept frozen at $-80^{\circ} \mathrm{C}$ until DNA extraction.

Enumeration of bacteria and phytoplankton. Total bacteria in the water samples were stained by 4,6 diamidino-2-phenylindole (DAPI), counterstained by acridine-orange (Crump et al. 1998) and enumerated in duplicate by epifluorescence microscopy on black $0.2 \mu \mathrm{m}$ Nuclepore filters (Porter \& Feig 1980). Phytoplankton cells were counted by inverted microscopy (Utermöhl 1958). Depending on the sediment load, 3 to 10 replicates per sample were counted. Phytoplankton species were identified according to Drebes (1974). To estimate phytoplankton biomass, cell numbers were multiplied by cell carbon. The latter was estimated

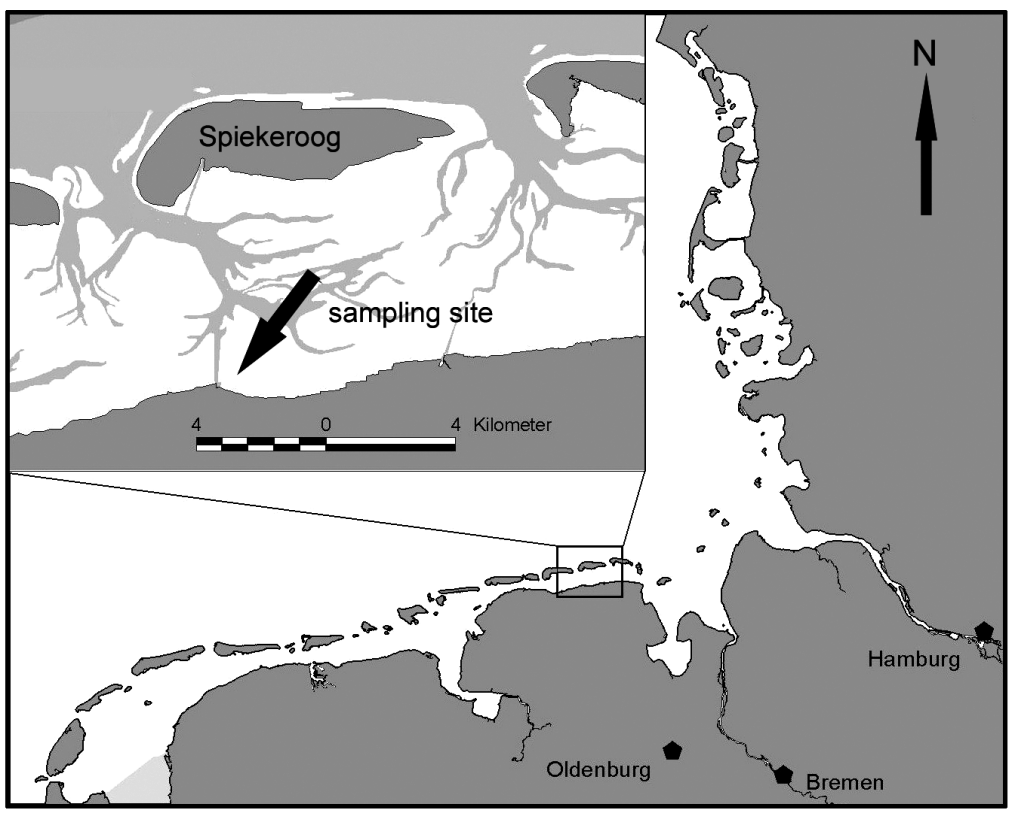

Fig. 1. Study area in the German Wadden Sea, southern North Sea 
from measured cell sizes of individual species converted to carbon according to empirical carbon/cell volume conversion factors from the Biologische Anstalt Helgoland (J. Berg unpubl. results).

Suspended particulate matter, particulate carbon and chlorophyll. For suspended particulate matter (SPM) and particulate carbon analysis, 200 to $500 \mathrm{ml}$ of seawater were filtered onto pre-weighed combusted $\left(550^{\circ} \mathrm{C}, 2 \mathrm{~h}\right)$ Whatman $\mathrm{GF} / \mathrm{F}$ filters immediately after return to the laboratory and kept frozen at $-20^{\circ} \mathrm{C}$ in the dark until further processing. Filters were not rinsed with deionized water for salt removal to avoid any loss of particulate organic material, but dry weight (DW) was corrected for salt using a newly developed method which subtracts the amount of salt retained in the filter according to the ambient salinity and the pore volume of the filter (Lunau et al. 2003). DW of SPM was determined on pre-weighed GF/F filters after drying at $110^{\circ} \mathrm{C}$ for $1 \mathrm{~h}$. Total particulate carbon was determined by a coulometric method using a Coulomat 702-SO instrument (Ströhlein Instruments) according to Babu et al. (1999). Samples were combusted at $1350^{\circ} \mathrm{C}$ and titrated against $\mathrm{Ba}\left(\mathrm{ClO}_{4}\right)_{2}$. Particulate inorganic carbon (PIC) was also determined by a coulometric method (Coulometrics 5012, UIC). Prior to combustion at $950^{\circ} \mathrm{C}$, inorganic carbon of the samples was removed by treatment with $2 \mathrm{M}$ perchloric acid. $\mathrm{CO}_{2}$ produced was titrated against $\mathrm{Ba}\left(\mathrm{ClO}_{4}\right)_{2}$. Particulate organic carbon (POC) was determined as the difference between particulate carbon and PIC. For chlorophyll analysis, 200 to $500 \mathrm{ml}$ of seawater were filtered onto a Whatman GF/F filter immediately after return to the laboratory and kept frozen at $-20^{\circ} \mathrm{C}$ in the dark until further processing. Filters were extracted at $75^{\circ} \mathrm{C}$ in $90 \%$ ethanol, and concentrations of chlorophyll a (chl a) were determined by standard procedures (Parsons et al. 1984). Phaeopigment concentrations were measured after acidification.

DNA extraction. Bacterial genomic DNA of filtered water and sediment samples was isolated after bead beating, phenol-chloroform extraction, and isopropanol precipitation as described previously (Stahl et al. 1988, MacGregor et al. 1997) but slightly modified. Treatment by sodium-dodecyl-sulfate (SDS, $1.75 \%$ of a $25 \%$ solution) was applied instead of lysozyme, precipitation done at $-20^{\circ} \mathrm{C}$ and molecular grade water (Eppendorf) was used for resuspension at $4^{\circ} \mathrm{C}$ overnight.

PCR amplification of 16S rRNA gene fragments. Primers GM5F (341F) and 907R (Muyzer et al. 1998)

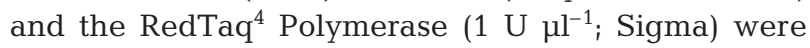
used to amplify $550 \mathrm{bp}$ fragments of 16S rRNA genes. At the 5' end of the GM5F primer, an additional 40nucleotide GC-rich sequence (GC-clamp) was added for DGGE analysis (Muyzer et al. 1993). A 'touchdown' PCR (Don et al. 1991) was performed (67 to $55^{\circ} \mathrm{C}$, step-down $1^{\circ} \mathrm{C}$ every second cycle) as described by Brinkhoff \& Muyzer (1997). Altogether, the PCR program included 26 cycles. Aliquots $(4 \mu \mathrm{l})$ of the amplicons were analyzed in $2 \%(\mathrm{w} / \mathrm{v})$ agarose gels and stained with ethidium bromide $\left(1 \mu \mathrm{g} \mathrm{ml}^{-1}\right)$ (Sambrook et al. 1989). For reamplifying the fragments, the primer GM5F was used without a clamp, and annealing temperature was $55^{\circ} \mathrm{C}$ without touch-down.

DGGE analysis of PCR products. DGGE was performed as described by Brinkhoff \& Muyzer (1997) with the D-Code system (Bio-Rad Laboratories). Briefly, $1 \mathrm{~mm}$-thick, 6\% (w/v) polyacrylamide gels, 1 TAE electrophoresis buffer $(40 \mathrm{mM})$, Tris- $\mathrm{HCl}$ (pH 8.3), $20 \mathrm{mM}$ acetic acid, 1 mM EDTA, 20 to $70 \%$ denaturant, and an electrophoresis time of $20 \mathrm{~h}$ at a constant voltage of $100 \mathrm{~V}$ and a constant temperature of $60^{\circ} \mathrm{C}$ were used. The gels were stained with SYBR Gold (Molecular Probes) and documented by a BioDoc Analyze Transilluminator (Biometra). The number of bands per lane was determined on various DGGE images with different exposure times such that all bands were detected. Here we present images for the 3 communities with the highest numbers of visible bands in a given image. Analysis of the DGGE banding patterns was done using a cluster analysis with the software package GelCompar II, version 2.5 (Applied Maths). We applied 5 to $20 \%$ background subtraction depending on the signal-to-noise ratio of the gel. Patterns were compared curve-based using Pearson correlation as similarity coefficient and UPGMA (unpaired group method of analysis) to generate the dendrogram. We used the position tolerance optimization option of the software to fit the curves to the best possible matching. From the given cophenetic correlation values and the similarity values for the internal standards, the most likely result was chosen. We used the curve-based approach instead of comparing single bands because Ferrari \& Hollibaugh (1999) and Selje \& Simon (2003) showed this analysis to be more robust. Twenty-four bands of interest, i.e. persisting and dominant bands, and those occurring only seasonally or once, were excised from the gel by a scalpel, and the DNA was eluted into $50 \mu \mathrm{l}$ molecular grade water (Eppendorf) by incubation at $4{ }^{\circ} \mathrm{C}$ overnight. The fragments were amplified using PCR conditions as described above. Purity of the bands and their migration behavior were checked by DGGE. For subsequent sequence analysis, PCR products of DGGE bands were purified using the Qiaquick PCR purification kit (Qiagen).

Cloning. Sixteen DGGE bands which could not be directly sequenced (FL-2, -3, -5, -6, -7; AG-4, -5, -6, -7, -9; SE-1, -2, -3,-4,-5,-7) were first cloned using the pGEM $^{\circledR}$-T Vector System II (Promega) according to the technical manual of the manufacturer. Clones with an insert were picked (10 for each band to be sequenced) 
with sterile toothpicks and directly transferred into a PCR-reaction mix. Amplicon length was checked on agarose gel after PCR with primers pUC/M13 forward and pUC/M13 reverse (Messing 1983) without touchdown (annealing temperature of $48^{\circ} \mathrm{C}$ ). Finally, DGGE migration behavior of 5 clones was examined after PCR amplification with primers as described for DGGE analysis. Only clones with an insert of the correct length and with the same migration behavior as the original sample in a DGGE gel were sequenced, 1 for each band cloned.

Sequencing and phylogenetic analysis. DGGE bands and clones were sequenced using the DYEnamic direct cycle sequencing kit (Amersham Life Science) and a Model 4200 Automated DNA Sequencer (Li-Cor). Sequencing primers were GM5F (341F) and 907R (Muyzer et al. 1998) labeled with IRDye ${ }^{\mathrm{TM}} 800$. Sequences without the primer sequence were compared to those in GenBank using the BLAST function of the National Center for Biotechnology Information (NCBI) server (www.ncbi.nlm.nih.gov). Phylogenetic analysis was performed with the ARB software package (Ludwig et al. 2004). For tree calculation, only sequences with more than $1300 \mathrm{bp}$ were considered using maximum likelihood analysis. Alignment positions at which less than $50 \%$ of sequences of the entire data set had the same residues were excluded from the calculations to prevent uncertain alignments within highly variable positions of the $16 \mathrm{~S}$ rRNA genes, which could cause mistakes in tree topology. Shorter sequences were added later to the final tree using the maximum parsimony option of the ARB program and the same filter.

The sequences obtained in this study are available from GenBank under accession no. AY274227 to AY274250.

\section{RESULTS}

\section{Physico-chemical parameters}

The surface water temperature from June to September 1999 ranged from 17 to $22.5^{\circ} \mathrm{C}$ and decreased thereafter until January 2000, reaching a minimum of $3^{\circ} \mathrm{C}$. By May 2000 it had risen again to $16^{\circ} \mathrm{C}$ (Fig. 2A). pH and oxygen saturation remained rather constant throughout the investigation period, ranging between 7.5-7.9 and 86-95\%, respectively. Salinity ranged from 21 to 32 psu (practical salinity units), with lowest values in December 1999 and March 2000 and highest values in September 1999 and May 2000 (Fig. 2A). A T/S (temperature/ salinity) plot identified 2 major water masses: one with high salinity and high temperatures which occured in the summer-fall period, including June to September 1999 and May and June 2000, and another with low salinity and low temperatures which occured in the late fall to spring period, including October 1999 and January to April 2000 (data not shown). In November 1999, salinity was not measured. In December, rainfall was twice the long-term mean (140 to $160 \mathrm{~mm} \mathrm{mo}^{-1}$ ), resulting in a high run-off and thus a reduced salinity. Therefore, the December T/S value did not correspond to either of the water masses. Wind speed varied greatly with lowest values in September 1999 and May $2000\left(<5 \mathrm{~m} \mathrm{~s}^{-1}\right)$ and highest values in February 2000 $\left(>20 \mathrm{~m} \mathrm{~s}^{-1}\right.$ ). Wind direction was quite variable, but only in November 1999 did the wind blow from the north-northeast (Fig. 2B).

\section{Suspended particulate matter and particulate carbon}

SPM ranged between 66 and $700 \mathrm{mg} \mathrm{DW} \mathrm{l}^{-1}$, with lowest values in August-October 1999 and May- June 2000, and highest values in November 1999 and February 2000 (Fig. 3B). Seasonal dynamics of particulate carbon, ranging between 0.4 and $19.1 \mathrm{mg} \mathrm{C} \mathrm{l}^{-1}$, basically followed those of SPM, with lowest and highest values in the same months (Fig. 3C). POC concentrations ranged between $0.13 \mathrm{mg} \mathrm{C}^{-1}$ in August 1999 and $9.7 \mathrm{mg} \mathrm{C}^{-1}$ in November 1999 and always comprised $<2.2 \% \mathrm{DW}$.

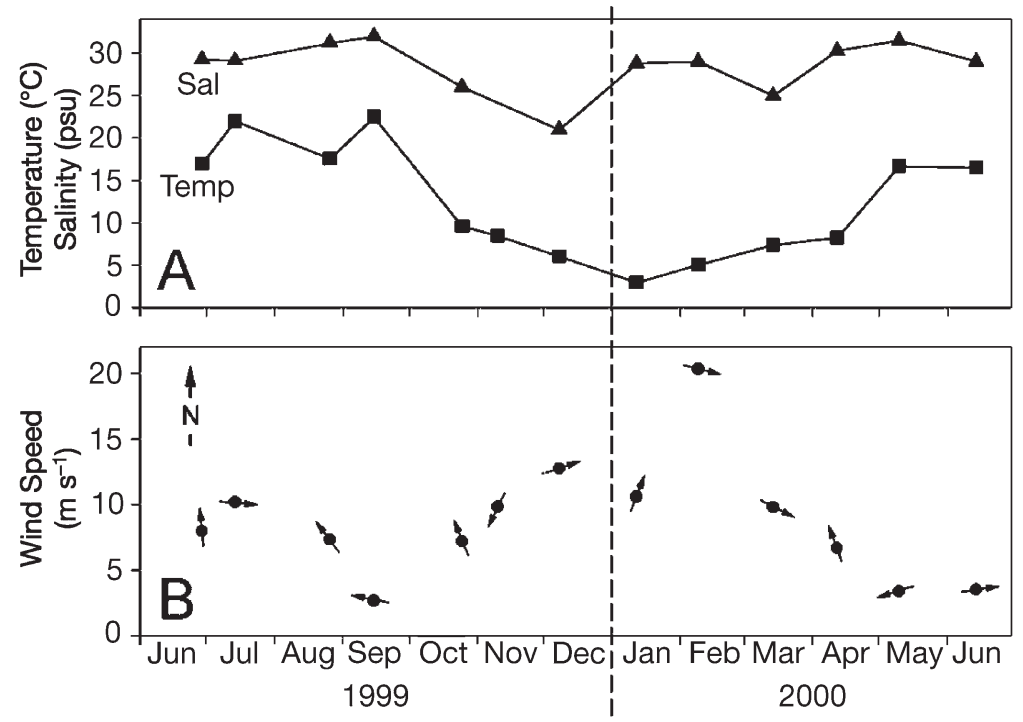

Fig. 2. Physico-chemical data from the German Wadden Sea between June 1999 and June 2000. (A) Water temperature (Temp), salinity (Sal); (B) wind speed. Wind data (mean of $12 \mathrm{~h}$ before sampling) are from Spiekeroog (island $8 \mathrm{~km}$ offshore the sampling site). Arrows indicate the wind direction; vertical dashed line marks the turn of the year 


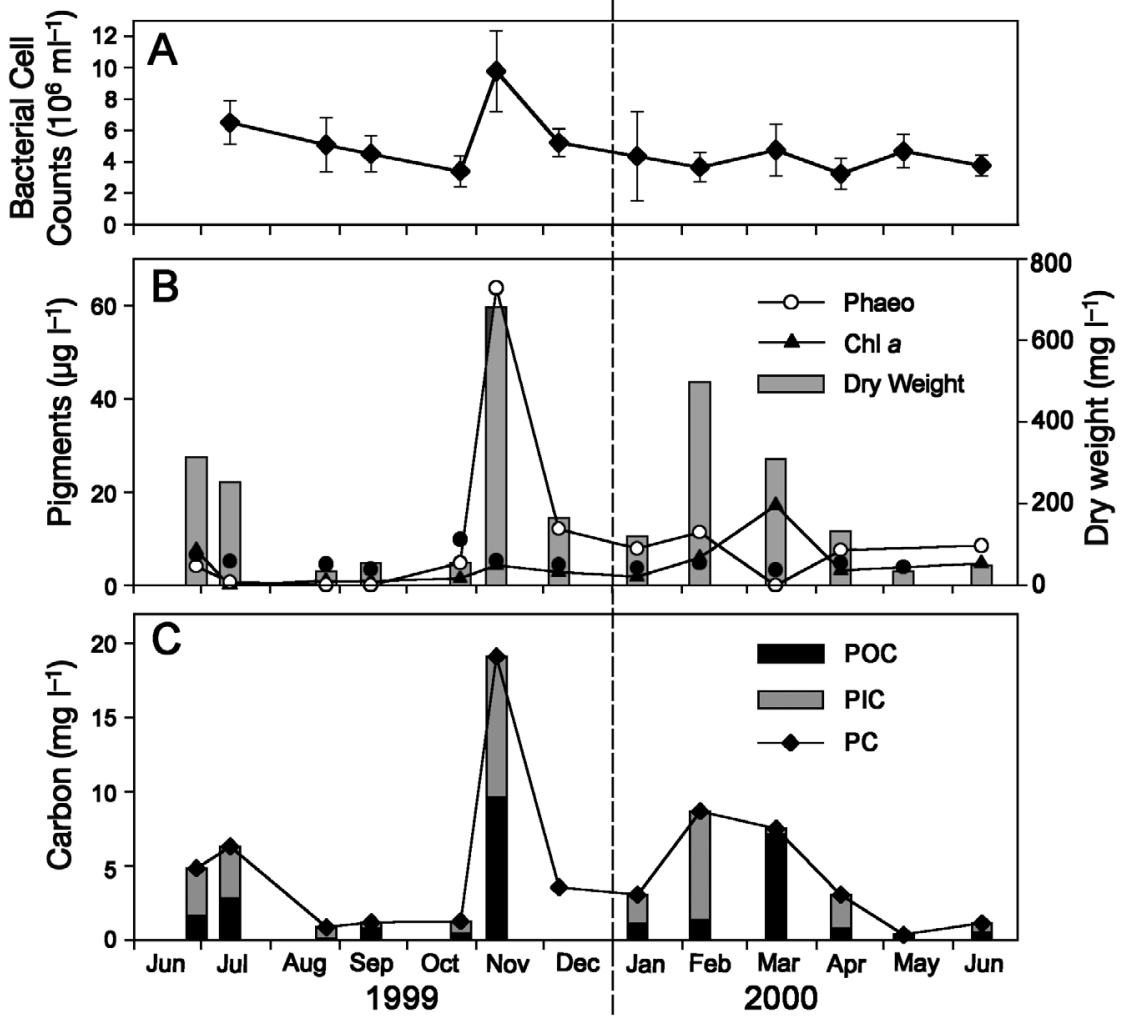

Fig. 3. (A) Bacterial cell counts; (B) concentrations of pigments (phaeopigments, chl a) and suspended matter dry weight; (C) particulate organic carbon (POC), particulate inorganic carbon (PIC), and particulate carbon (PC) in the German Wadden Sea between June 1999 and June 2000. Vertical dashed line marks the turn of the year

\section{Chlorophyll $a$, phytoplankton, and bacterial cell numbers}

Chl a concentrations ranged from $<1$ $\mu \mathrm{g} \mathrm{l^{-1 }}$ in July 1999 to $17.1 \mu \mathrm{g} \mathrm{l}^{-1}$ in March 2000, when a pronounced spring bloom occurred (Fig. 3B). Phaeopigment concentrations exhibited large variations, with lowest values near the detection limit $\left(0.2 \mu \mathrm{g} \mathrm{l}^{-1}\right)$ from July to September 1999 and in March 2000, and enhanced values between October 1999 and February 2000. The maximum of $63.8 \mu \mathrm{g} \mathrm{l}^{-1}$ occurred in November 1999.

Phytoplankton cell counts, determined since August 1999, ranged between $3.9 \times$

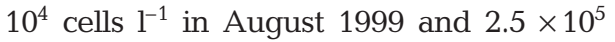
cells $\mathrm{l}^{-1}$ at the spring bloom in March 2000. Cell counts fluctuated around $510^{4}$ cells l $^{-1}$ until January 2000 (Fig. 4A). The enhanced cell number in February 2000 was presumably due to resuspension, as indicated by the wind speed and direction (Fig. 2B). Diatoms always dominated the phytoplankton, but small unidentified chlorophytes constituted $\sim 4$ to $34.8 \%$ (Fig. 4B). Even though most of the phytoplankton algae were determined on the species level, we pooled them for clarity and present data on the genus and higher taxonomical lev-

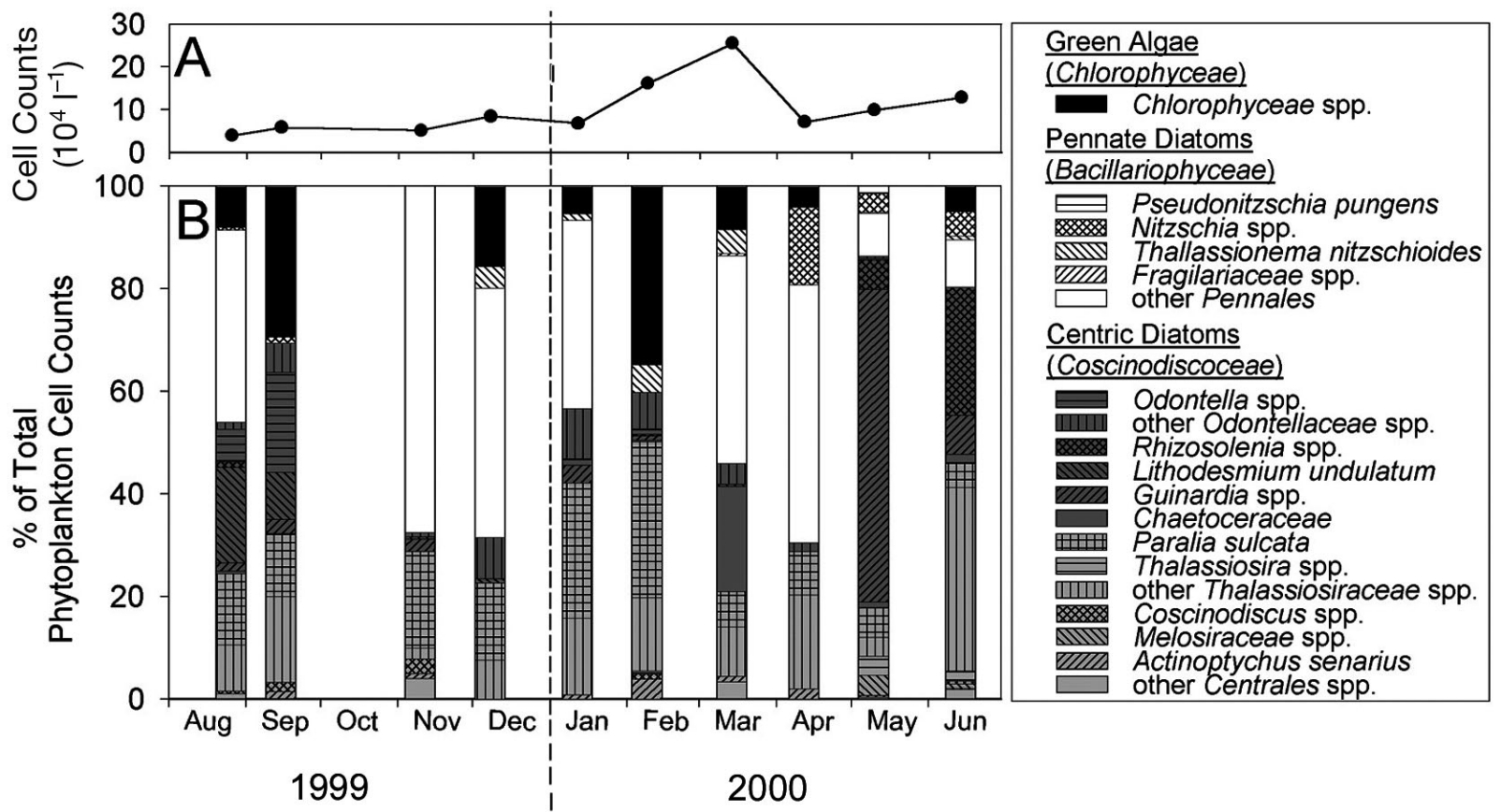

Fig. 4. (A) Phytoplankton cell numbers; (B) composition (\% of total numbers) of the phytoplankton community in the German Wadden Sea between August 1999 and June 2000. Vertical dashed line marks the turn of the year 
els. Most of the diatoms were typical planktonic forms, e.g. Chaetoceros spp., Guinardia spp., Nitzschia spp., Odontella spp., Rhizosolenia spp., and Thalassiosira spp. While Thalassiosira spp. were present in all samples, other species occurred with seasonal peaks: Odontella spp. in August and September 1999, Chaetoceros spp. during the spring bloom in March 2000, Nitzschia spp. from April to June 2000 and Guinardia spp. and Rhizosolenia spp. in May and June 2000. Benthic diatoms, in particular Paralia sulcata, always constituted substantial proportions. In August and September 1999, Lithodesmium undulatum and P. sulcata constituted 32.4 and $21.6 \%$ of total algal cell counts, respectively, and the latter also $31 \%$ in January and February 2000.

Phytoplankton biomass (PhytoC) ranged between $23.3 \mu \mathrm{g} \mathrm{Cl}^{-1}$ in April 2000 and $234.5 \mu \mathrm{g} \mathrm{Cl}^{-1}$ in November 1999 (data not shown), when the large diatom Coscinodiscus wailesii constituted high proportions despite relatively low cell numbers (Fig. 4B). The ratio of PhytoC/POC varied greatly. Lowest values of $<3 \%$ occurred in January, March and April 2000, whereas in August and September 1999 and in May 2000, 31, 63 and $83 \%$, respectively, were recorded (data not shown).

Bacterial numbers continuously decreased from July to October 1999 from $6.5 \times 10^{6}$ to $3.4 \times 10^{6}$ cells ml $^{-1}$ (Fig. 3A). After the absolute maximum in November 1999 of $9.7 \times 10^{6}$ cells $\mathrm{ml}^{-1}$, numbers remained fairly stable around $4 \times 10^{6}$ cells ml ${ }^{-1}$ without any significant response to POC or phytoplankton dynamics.

\section{Correlation analysis}

In order to identify potentially important variables controlling the seasonal dynamics of suspended matter, phytoplankton and bacterial abundance, we performed a correlation analysis using the software STATISTICA (StatSoft). Data were log-transformed prior to analysis to fit a log-normal distribution. Wind speed was significantly correlated with most fractions of suspended matter such as SPM, particulate carbon, and POC (Table 1). Chl a was significantly correlated with SPM, particulate carbon, POC, and phytoplankton cell numbers. Bacterial numbers did not show any significant correlation for the entire data set. In summer (data of June-September 1999 and May and June 2000) bacterial numbers correlated significantly with phaeopigments, but only 4 data points are included in this analysis. When cold-water masses prevailed between October 1999 and April 2000, bacterial cell numbers were significantly correlated with POC.

\section{Bacterial community structure}

The DGGE analysis showed distinct differences between the banding patterns of the free-living, aggregate-associated and sediment surface-associated bacterial communities (Fig. 5). Results for free-living bacteria from December 1999 and January 2000 are not available due to problems with DNA extraction. Banding patterns of the aggregate-associated community exhibited the highest number of bands per lane, and also the greatest temporal variations. During most of the study period, 20 (February 2000) to 30 bands (May 1999) were recorded, whereas in May 2000 only 12 bands occurred. The overall mean of all aggregateassociated bacterial samples was $24 \pm 5$ bands. The number of bands per lane for the free-living bacterial fraction varied least and absolute numbers were lower,

Table 1. Correlation analysis of wind speed (WS), chl $a_{1}$ and bacterial numbers (BN) with water temperature (Temp), suspended matter dry weight (DW), particulate carbon (PC), particulate organic carbon (POC), chl a, phaeopigments (Phaeo), and phytoplankton cell numbers (PhytoN). Pearson product-moment correlation coefficients $\left(\mathrm{r}^{2}\right)$ and number of samples (given in parentheses) are shown. Analysis of log-transformed data was done for the entire study period (June 1999 to June 2000), for the warmer months (June to September 1999, May and June 2000) and for the colder months (October 1999 to April 2000). Significant correlations $(\mathrm{p}<0.05)$ are in bold; \#: correlations with $\mathrm{r}^{2}<0.45$; X: auto-correlation

\begin{tabular}{|c|c|c|c|c|c|c|c|c|c|c|c|c|c|}
\hline & WS & Temp & \multicolumn{2}{|c|}{ DW } & \multicolumn{2}{|c|}{$\mathrm{PC}$} & \multicolumn{2}{|c|}{ POC } & \multicolumn{2}{|c|}{ Chl a } & Phaco & \multicolumn{2}{|c|}{ PhytoN } \\
\hline \multicolumn{14}{|c|}{ June 1999 to June 2000} \\
\hline WS & $\mathrm{X}$ & -0.51 & 0.66 & $(13)$ & 0.68 & (13) & 0.67 & $(12)$ & 0.54 & $(11)$ & \# & 0.49 & (11) \\
\hline Chl a & 0.54 & (11) & 0.63 & (11) & 0.69 & (11) & 0.80 & (10) & $\mathrm{X}$ & & \# & 0.86 & (11) \\
\hline $\mathrm{BN}$ & \# & \# & 0.51 & $(12)$ & 0.46 & $(12)$ & 0.51 & $(11)$ & \# & & \# & \# & \\
\hline \multicolumn{14}{|c|}{ June to September 1999, May and June 2000} \\
\hline WS & $\mathrm{X}$ & \# & 0.72 & (6) & 0.78 & (6) & 0.84 & (6) & 0.66 & (4) & 0.52 & \# & \\
\hline Chl $a$ & 0.66 & -0.70 & 0.51 & $(4)$ & 0.75 & $(4)$ & 0.97 & $(4)$ & $\mathrm{X}$ & & $0.91 \quad(4)$ & 0.93 & (3) \\
\hline $\mathrm{BN}$ & $0.84(5)$ & $0.57 \quad(5)$ & 0.78 & (5) & 0.64 & (5) & 0.53 & $(5)$ & \# & & $\mathbf{0 . 9 4}$ & $\#$ & \\
\hline \multicolumn{14}{|c|}{ October 1999 to April 2000} \\
\hline WS & $\mathrm{X}$ & \# & 0.47 & (7) & \# & & \# & & \# & & \# & 0.60 & (6) \\
\hline Chl a & \# & \# & 0.66 & (7) & 0.66 & (7) & 0.72 & (6) & $\mathrm{X}$ & & $0.71 \quad(7)$ & 0.84 & (6) \\
\hline $\mathrm{BN}$ & \# & \# & 0.63 & (7) & 0.73 & (7) & 0.84 & (6) & \# & & \# & \# & \\
\hline
\end{tabular}



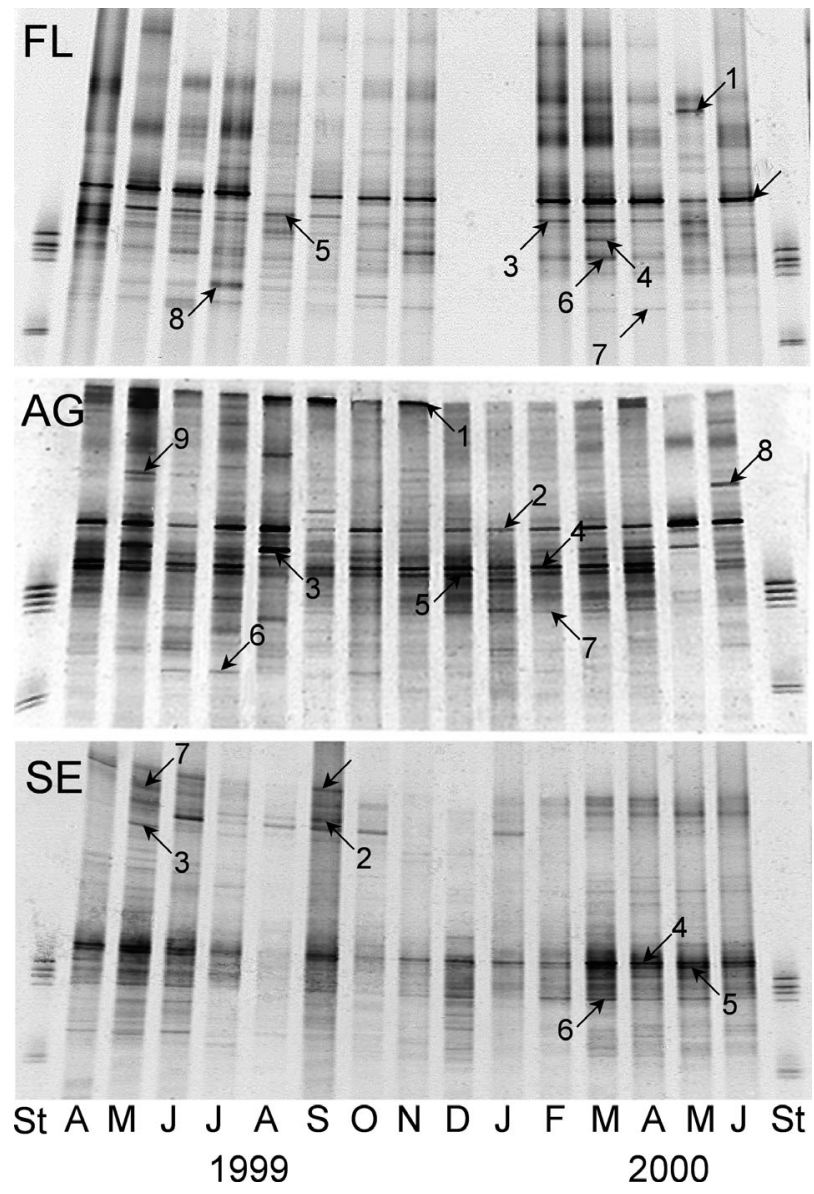

Fig. 5. Inverted images of DGGE banding patterns of PCR amplified 16S rRNA gene fragments of the free-living (FL), aggregate-associated (AG) and sediment surface-associated (SE) bacterial communities in the German Wadden Sea between April 1999 and June 2000. Arrows and numbers denote sequenced bands; vertical dashed line marks the turn of the year. St: standard

ranging between 17 in May 1999 and April 2000 and 24 in October and November 1999 with a mean of $20 \pm$ 2. The number of bands per lane for the sediment surface-associated community was lowest, varying between 9 bands in January 2000 and 25 bands in March 2000 with a mean of $17 \pm 5$. This number was significantly lower $(p=0.025)$ than that of the aggregate-associated bacterial community, but not statistically different from that of the free-living bacterial community (ANOVA test).

In all 3 fractions, some bands persisted throughout the entire study period, albeit at varying intensity, such as Bands FL-2 and FL-3 in the free-living bacterial fraction, Bands AG-2, AG-4 and AG-5 in the aggregate-associated fraction, and Bands SE-4, SE-5, and SE-6 in the sediment surface-associated fraction (Fig. 5). Other bands only occurred during certain peri- ods or only once. Band FL-6 only occurred between November 1999 and April 2000, Band FL-7 between March and May 2000, and Band FL-1 in May 2000. In the aggregate-associated bacterial fraction, Band AG6 was detected between May and July and in October 1999. Bands SE-1, SE-2, SE-3, and SE-7 of the sediment surface-associated bacterial fraction only occurred between May and September 1999.

The cluster analysis substantiated that the 3 fractions constituted different communities (Fig. 6). The sediment surface-associated community formed a distinct cluster with similarities of $>78 \%$ (Pearson correlation) of all samples, except those from August and October 1999. Between March and June 2000, a stable community was established, as documented by a particularly narrow subcluster for this period. The aggregateassociated and free-living bacterial fractions exhibited different clusters, but the subcluster of aggregate-associated bacteria from May 1999 and 2000 and June 2000 and August 1999 was more similar to that of free-living bacterial communities than to that of other aggregateassociated bacteria. In general, the aggregate-associated bacterial fraction was more similar to the sediment surface-associated fraction than to the free-living fraction. Aggregate-associated bacteria from April 1999 and December 1999 to April 2000 formed a distinct subcluster, thus reflecting the cold-water masses identified by a T/S plot (see 'Physico-chemical parameters'), but possibly also the fact that Band AG-1, identified as a chloroplast sequence (Table 2), was absent during this time. Free-living bacteria from April and August 1999 and May 2000 formed a subcluster more similar to that of aggregate-associated bacteria than to that of other free-living bacteria. The latter formed a well-separated cluster with similarities of $>78 \%$.

Conspicuous bands of all 3 fractions were excised, sequenced and phylogenetically analyzed. Eight sequences affiliated with $\alpha$-Proteobacteria, 1 with $\beta$ Proteobacteria, 6 with $\gamma$-Proteobacteria, 2 with $\delta$-Proteobacteria, 3 with the Flavobacteria/Sphingobacteria group, 1 with Actinobacteria, and 5 sequences were identified as plastid-like, 3 of them occurring in the sediment surface and 1 each in the free-living and the aggregate-associated communities (Table 2, Fig. 7). Phylotypes were identified by their origin (German Wadden Sea [GWS], bacterial subcommunity [FL, AG, SE] and number as shown in Fig. 5).

Phylotypes of $\alpha$-Proteobacteria were retrieved only from the fractions of free-living and aggregate-associated bacteria and constituted 4 of the 8 phylotypes from the free-living bacterial community, including the dominant phylotypes GWS-FL-2, -FL-3, and -FL-5 (Fig. 5). The dominant DGGE band of phylotype GWSAG-2 of the aggregate-associated fraction affiliated also with $\alpha$-Proteobacteria and was identical to GWS- 


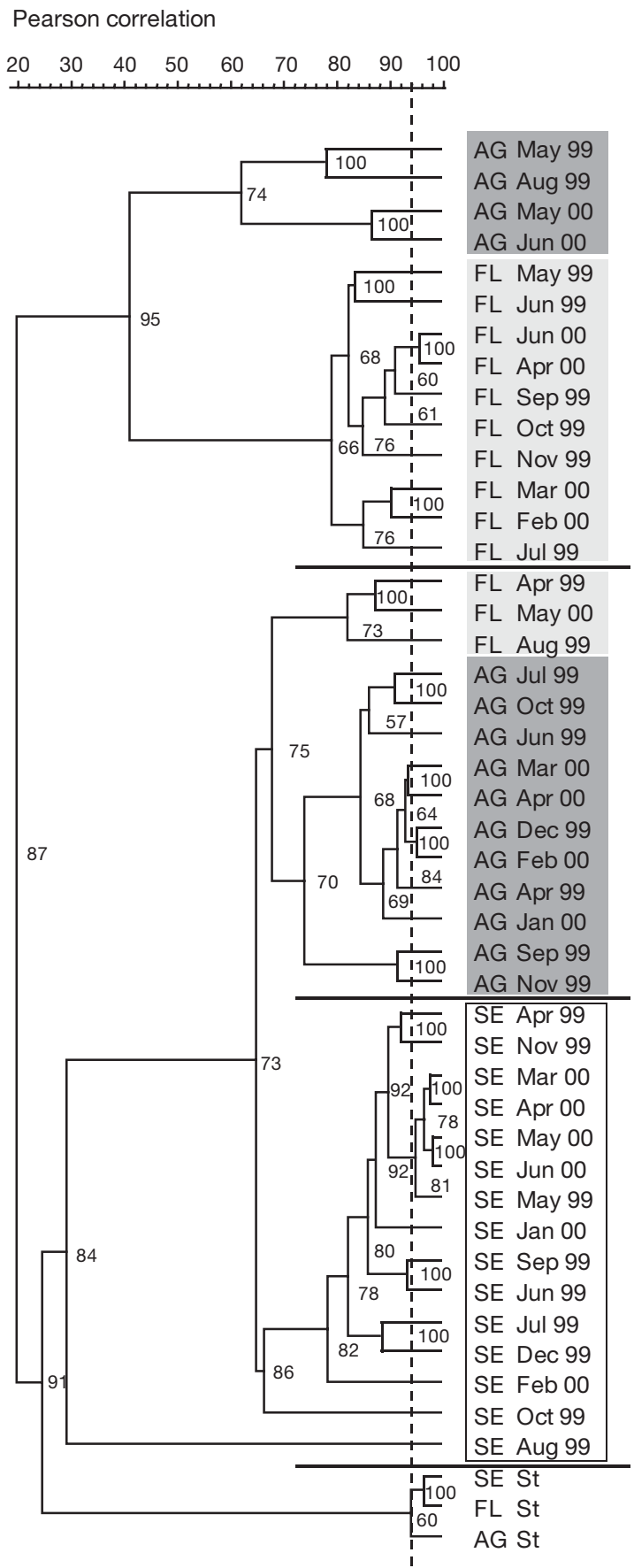

Fig. 6. Curve based cluster analysis (UPGMA, unpaired group method of analysis) of DGGE banding patterns of the free-living (FL), aggregate-associated (AG) and sediment surface-associated (SE) bacterial communities in the German Wadden Sea between April 1999 and June 2000. The Pearson coefficient was used to calculate levels of similarity between the patterns of 3 different DGGE gels. The same standard was used on all gels. Comparison of the standard from the different gels shows the gels being comparable from $93 \%$ of the Pearson correlation (vertical dashed line). Numbers in the branches indicate the calculated cophenetic correlations of each branching; clusters of the various fractions are boxed or shaded gray. St: standard
FL-2. The sequence of Band GWS-FL-6 affiliated with $\beta$-Proteobacteria and represented the only phylotype of this phylogenetic subgroup. Three of the 6 phylotypes affiliating with $\gamma$-Proteobacteria occurred in the aggregate-associated bacterial community and 2 of them represented prominent members (GWS-AG-4, GWS-AG-5). One phylotype from the free-living fraction (GWS-FL-7) and 2 of the sediment surface-associated bacterial fraction affiliated with $\gamma$-Proteobacteria (GWS-SE-4, GWS-SE-5). Phylotype GWS-SE-5 shows a $99 \%$ sequence similarity to phylotype GWS-AG-5. The 2 phylotypes affiliating with $\delta$-Proteobacteria of the aggregate-associated (GWS-AG-7) and sedimentassociated fractions (GWS-SE-6) exhibited a sequence similarity of $98 \%$ to each other. Phylotypes affiliating with the Flavobacteria/Sphingobacteria group were detected only in the aggregate- and sediment surfaceassociated fractions such as in May 1999 and June 2000 (GWS-AG-8, -AG-9, -SE-7; Fig. 5, Table 2).

\section{DISCUSSION}

The strong hydrodynamic forcing, rapid restructuring of the composition and size structure of suspended aggregates and intense sedimentation and resuspension processes in shallow and turbid ecosystems like the Wadden Sea have been well studied (Wainright 1990, 1997, Milligan 1995, Van Leussen 1996, Jago et al. 2002, McCandliss et al. 2002); however, how these affect the composition of bacterial communities in such environments has not yet been studied. Our results show differences in the banding patterns and number of bands in the free-living, aggregateassociated and sediment surface-associated bacterial communities, resulting in separate clusters, which prevailed throughout most of the study period. Obviously, specific bacterial communities persisted in the 3 habitats, despite the strong hydrodynamic forcing and rapid restructuring of the suspended aggregates. Some phylotypes, however, were found in the free-living as well as in the aggregate-associated fraction, or in the latter as well as in the sediment surface-associated community. These notions reflect that transitions and exchange processes occurred between the free-living and aggregate-associated communities and between the sediment surface-associated and the aggregate-associated communities. The fact that some bands were present only in the free-living and aggregate-associated communities but not in the sediment-associated community indicates that the aggregates were not just a vehicle between the water column and the sediment surface but that they harbour a specific community with mediating features between the 2 other communities. 
Table 2. Phylogenetic affiliation of sequences obtained from DGGE bands from samples of the German Wadden Sea taken between April 1999 and June 2000. Given are phylogenetic affiliation, band identification (ID), number of base pairs (bp) of the sequence, accession number (Acc. no.), date of sampling (Date) and sequence similarity to the closest phylotype and described species (type strain) as retrieved by BLAST analysis (www.ncbi.nlm.nih.gov/blast). The type species are validly published in the 'International Journal of Systematic and Evolutionary Microbiology'. ID of the bands refer to those indicated in Fig. 5. FL: free-living; AG: aggregate-associated; SE: sediment-associated; ND: not denoted

\begin{tabular}{|c|c|c|c|c|c|}
\hline Group & $\begin{array}{l}\text { Band ID (bp), } \\
\text { (Acc. no.) }\end{array}$ & Date & $\begin{array}{l}\text { Closest phylotype or } \\
\text { species (Acc. no.) }\end{array}$ & $\begin{array}{l}\text { Similarity } \\
(\%)\end{array}$ & $\begin{array}{l}\text { Remarks on closest phylotype/ } \\
\text { relative }\end{array}$ \\
\hline \multicolumn{6}{|l|}{ Free-living } \\
\hline \multirow[t]{2}{*}{ Eukarya } & \multirow[t]{2}{*}{$\begin{array}{l}\text { GWS-FL-1 (517), } \\
(\mathrm{AY} 274227)\end{array}$} & \multirow[t]{2}{*}{ May 00} & $\begin{array}{l}\text { Uncultured bacterium } \\
\text { clone RCP2-13 } \\
\text { (AF523902) }\end{array}$ & 97 & Environmental wetland sample \\
\hline & & & $\begin{array}{l}\text { Algal chloroplast } \\
\text { (AF514855) }\end{array}$ & 97 & Chloroplast of Haslea wawrikae \\
\hline \multirow[t]{8}{*}{$\alpha$-Proteobacteria } & \multirow[t]{2}{*}{$\begin{array}{l}\text { GWS-FL-2 (533), } \\
\text { (AY274228) }\end{array}$} & \multirow[t]{2}{*}{ Jun 00} & $\begin{array}{l}\text { Uncultured alpha proteo- } \\
\text { bacterium clone DC11-80-2 } \\
\text { (AY145625) }\end{array}$ & 99 & $\begin{array}{l}\text { DGGE band, } 10^{-6} \text { dilution culture } \\
\text { of the polyhaline } \\
\text { section of the Weser estuary }\end{array}$ \\
\hline & & & Ruegeria gelatinovorans (D88523) & 94 & Environmental marine sample \\
\hline & \multirow[t]{2}{*}{$\begin{array}{l}\text { GWS-FL-3 (522), } \\
\text { (AY274229) }\end{array}$} & \multirow[t]{2}{*}{ Feb 00} & $\begin{array}{l}\text { Uncultured alpha proteo- } \\
\text { bacterium clone DC5-80-8 } \\
\text { (AY145594) }\end{array}$ & 99 & $\begin{array}{l}\text { DGGE band, } 10^{-5} \text { dilution culture } \\
\text { of the polyhaline section of the } \\
\text { Weser estuary }\end{array}$ \\
\hline & & & Ruegeria gelatinovorans (D88523) & 96 & Environmental marine sample \\
\hline & \multirow[t]{2}{*}{$\begin{array}{l}\text { GWS-FL-4 (430), } \\
\text { (AY274230) }\end{array}$} & \multirow[t]{2}{*}{ Mar 00} & $\begin{array}{l}\text { Brevundimonas vesicularis } \\
\text { (AY169433) }\end{array}$ & 99 & \multirow[t]{2}{*}{$\begin{array}{l}\text { Low temperature anaerobic } \\
\text { enrichment of a Greenland ice } \\
\text { core sample from } 3042 \mathrm{~m} \text { depth }\end{array}$} \\
\hline & & & Brevundimonas vesicularis (AJ227780) & 99 & \\
\hline & \multirow[t]{2}{*}{$\begin{array}{l}\text { GWS-FL-5 (525), } \\
\text { (AY274231) }\end{array}$} & \multirow[t]{2}{*}{ Aug 99} & $\begin{array}{l}\text { Uncultured alpha proteo- } \\
\text { bacterium isolate WM11-36 } \\
\text { (AF497864) }\end{array}$ & 98 & $\begin{array}{l}\text { DGGE band, polyhaline section of } \\
\text { the Weser estuary, November } \\
1999\end{array}$ \\
\hline & & & Sulfitobacter pontiacus (Y13155) & 96 & Environmental Black Sea sample \\
\hline \multirow[t]{2}{*}{$\beta$-Proteobacteria } & \multirow[t]{2}{*}{$\begin{array}{l}\text { GWS-FL-6 (223), } \\
\text { (AY274232) }\end{array}$} & \multirow[t]{2}{*}{ Nov 99} & $\begin{array}{l}\text { Uncultured beta proteobac- } \\
\text { terium clone DC11-51-11 } \\
\text { (AY145622) }\end{array}$ & 97 & \multirow[t]{2}{*}{$\begin{array}{l}\text { DGGE band, } 10^{-5} \text { dilution culture } \\
\text { of the brackish section of the } \\
\text { Weser estuary }\end{array}$} \\
\hline & & & Leptothrix mobilis (X97071) & 96 & \\
\hline \multirow[t]{2}{*}{$\gamma$-Proteobacteria } & \multirow[t]{2}{*}{$\begin{array}{l}\text { GWS-FL-7 (534), } \\
\text { (AY274233) }\end{array}$} & \multirow[t]{2}{*}{ Apr 00} & $\begin{array}{l}\text { Halomonas sp. ARD M36 } \\
\text { (AB085657) }\end{array}$ & 100 & \multirow[t]{2}{*}{$\begin{array}{l}\text { Environmental terrestrial sample } \\
\text { (Antarctica) }\end{array}$} \\
\hline & & & Halomonas meridiana (AJ306891) & 99 & \\
\hline \multirow[t]{2}{*}{ Actinobacteria } & \multirow[t]{2}{*}{$\begin{array}{l}\text { GWS-FL-8 (526), } \\
\text { (AY274234) }\end{array}$} & \multirow[t]{2}{*}{ Jul 99} & $\begin{array}{l}\text { Uncultured actinobacterium clone } \\
\text { SAa03 (AY124414) }\end{array}$ & 99 & Environmental sample \\
\hline & & & Beutenbergia cavernae (Y18378) & 92 & Environmental cave sample \\
\hline \multicolumn{6}{|c|}{ Aggregate-associated } \\
\hline Eukarya & $\begin{array}{l}\text { GWS-AG-1 (533), } \\
\text { (AY274235) }\end{array}$ & Nov 99 & $\begin{array}{l}\text { Plastid of Skeletonema pseudo- } \\
\text { costatum (X82155) }\end{array}$ & 98 & \\
\hline \multirow[t]{4}{*}{$\alpha$-Proteobacteria } & \multirow[t]{2}{*}{$\begin{array}{l}\text { GWS-AG-2 (539), } \\
\text { (AY274236) }\end{array}$} & \multirow[t]{2}{*}{ Feb 00} & $\begin{array}{l}\text { Uncultured alpha proteo- } \\
\text { bacterium clone DC11-80-2 } \\
\text { (AY145625) }\end{array}$ & 99 & $\begin{array}{l}\text { DGGE band, } 10^{-6} \text { dilution culture } \\
\text { of the polyhaline section of the } \\
\text { Weser estuary }\end{array}$ \\
\hline & & & Ruegeria gelatinovorans (D88523) & 94 & Environmental marine sample \\
\hline & \multirow[t]{2}{*}{$\begin{array}{l}\text { GWS-AG-3 (457), } \\
\text { (AY274237) }\end{array}$} & \multirow[t]{2}{*}{ Aug 99} & $\begin{array}{l}\text { Rhodobacteraceae bacterium TL } \\
\text { (AY177716) }\end{array}$ & 94 & $\begin{array}{l}\text { Isolate from the German Wadden } \\
\text { Sea }\left(10^{-5} \text { dilution culture }\right)\end{array}$ \\
\hline & & & Ruegeria gelatinovorans (D88523) & 91 & Environmental marine sample \\
\hline$\gamma$-Proteobacteria & $\begin{array}{l}\text { GWS-AG-4 (545), } \\
\text { (AY274238) }\end{array}$ & Feb 00 & $\begin{array}{l}\text { Uncultured gamma proteobac- } \\
\text { terium Sva0318 (AJ240989) }\end{array}$ & 97 & Permanently cold marine sediment \\
\hline & & & Alkalilimnicola halodurans (AJ404972) & 90 & Sediments of soda-depositing lake \\
\hline & $\begin{array}{l}\text { GWS-AG-5 (547), } \\
\text { (AY274239) }\end{array}$ & Dec 99 & $\begin{array}{l}\text { Uncultured proteobacterium clone } \\
\text { Bol92 (AY193138) }\end{array}$ & 98 & Marine sediment \\
\hline & & & $\begin{array}{l}\text { Thiorhodovibrio winogradskyi } \\
\text { (AJ006214) }\end{array}$ & 91 & Cold lake sediment sample \\
\hline & GWS-AG-6 (544), & Jul 99 & Nitrosococcus halophilus (AF287298) & 88 & \\
\hline & $(\mathrm{AY} 274240)$ & & Nitrosococcus oceani (AF363287) & 89 & Marine sample \\
\hline
\end{tabular}


Table 2 (continued)

\begin{tabular}{|c|c|c|c|c|c|}
\hline Group & $\begin{array}{l}\text { Band ID (bp), } \\
\text { (Acc. no.) }\end{array}$ & Date & $\begin{array}{l}\text { Closest phylotype or } \\
\text { species (Acc. no.) }\end{array}$ & $\begin{array}{l}\text { Similarity } \\
(\%)\end{array}$ & $\begin{array}{l}\text { Remarks on closest phylotype/ } \\
\text { relative }\end{array}$ \\
\hline \multirow[t]{2}{*}{$\delta$-Proteobacteria } & \multirow[t]{2}{*}{$\begin{array}{l}\text { GWS-AG-7 (555), } \\
(\text { AY274241) }\end{array}$} & \multirow[t]{2}{*}{ Feb 00} & $\begin{array}{l}\text { Uncultured delta proteobacterium } \\
\text { clone D062 (AF367389) }\end{array}$ & 99 & $\begin{array}{l}\text { Environmental biofilm sample from } \\
\text { tidal creek (southeastern US) }\end{array}$ \\
\hline & & & Haliangium tepidum (AB062751) & 91 & $\begin{array}{l}\text { Environmental coastal marine } \\
\text { sample, moderately halophilic }\end{array}$ \\
\hline \multirow[t]{4}{*}{ Bacteroidetes } & \multirow[t]{2}{*}{$\begin{array}{l}\text { GWS-AG-8 (539), } \\
\text { (AY274242) }\end{array}$} & \multirow[t]{2}{*}{ Jun 00} & $\begin{array}{l}\text { Uncultured bacterium SB-42-DB } \\
\text { (AJ319829) }\end{array}$ & 96 & \multirow[t]{2}{*}{$\begin{array}{l}\text { Satellite bacterium of Dytilum } \\
\text { brightwellii }\end{array}$} \\
\hline & & & $\begin{array}{l}\text { Chryseobacterium meningosepticum } \\
\text { (AF207075) }\end{array}$ & 85 & \\
\hline & \multirow[t]{2}{*}{$\begin{array}{l}\text { GWS-AG-9 (308), } \\
\text { (AY274243) }\end{array}$} & \multirow[t]{2}{*}{ May 99} & $\begin{array}{l}\text { Uncultured Cytophagales QSSC9L-1 } \\
\text { (AF170779) }\end{array}$ & 93 & \multirow{2}{*}{$\begin{array}{l}\text { Antarctic quartz stone sublithic } \\
\text { communities } \\
\text { Marine species }\end{array}$} \\
\hline & & & Lewinella nigricans (AF039294) & 92 & \\
\hline \multicolumn{6}{|c|}{ Sediment surface-associated } \\
\hline \multirow[t]{4}{*}{ Eukarya } & $\begin{array}{l}\text { GWS-SE-1 (558), } \\
\text { (AY274244) }\end{array}$ & Sep 99 & $\begin{array}{l}\text { Plastid of Skeletonema } \\
\text { pseudocostatum (X82155) }\end{array}$ & 98 & \\
\hline & \multirow[t]{2}{*}{$\begin{array}{l}\text { GWS-SE-2 (524), } \\
\text { (AY274245) }\end{array}$} & \multirow[t]{2}{*}{ Sep 99} & $\begin{array}{l}\text { Uncultured vent bacterium ML-2d } \\
\text { (AF208994) }\end{array}$ & 97 & \multirow[t]{3}{*}{$\begin{array}{l}\text { Shallow submarine hydrothermal } \\
\text { vent near Milos island }\end{array}$} \\
\hline & & & $\begin{array}{l}\text { Chloroplast of Haslea wawrikae } \\
\text { (AF514855) }\end{array}$ & 97 & \\
\hline & $\begin{array}{l}\text { GWS-SE-3 (529), } \\
\text { (AY274246) }\end{array}$ & May 99 & $\begin{array}{l}\text { Chloroplast of Haslea nipkowii } \\
\text { (AF514850) }\end{array}$ & 99 & \\
\hline \multirow[t]{4}{*}{$\gamma$-Proteobacteria } & \multirow[t]{2}{*}{$\begin{array}{l}\text { GWS-SE-4 (548), } \\
\text { (AY274250) }\end{array}$} & \multirow[t]{2}{*}{ Apr 00} & $\begin{array}{l}\text { Uncultured bacterium clone s105 } \\
\text { (AY171392) }\end{array}$ & 100 & $\begin{array}{l}\text { Environmental marine sediment } \\
\text { sample }\end{array}$ \\
\hline & & & $\begin{array}{l}\text { Thiorhodovibrio winogradskyi } \\
\text { (AJ006214) }\end{array}$ & 90 & $\begin{array}{l}\text { Environmental lake sediment } \\
\text { sample }\end{array}$ \\
\hline & \multirow[t]{2}{*}{$\begin{array}{l}\text { GWS-SE-5 (548), } \\
\text { (AY274247) }\end{array}$} & \multirow[t]{2}{*}{ May 00} & $\begin{array}{l}\text { Uncultured proteobacterium clone } \\
\text { Bol92 (AY193138) }\end{array}$ & 98 & Environmental marine sample \\
\hline & & & $\begin{array}{l}\text { Alkalilimnicola halodurans } \\
\text { (AJ404972) }\end{array}$ & 91 & Sediments of soda-depositing lake \\
\hline \multirow[t]{2}{*}{$\delta$-Proteobacteria } & \multirow[t]{2}{*}{$\begin{array}{l}\text { GWS-SE-6 (515), } \\
\text { (AY274248) }\end{array}$} & \multirow[t]{2}{*}{ Mar 00} & $\begin{array}{l}\text { Uncultured delta proteobacterium } \\
\text { clone Hyd24-27 (AJ535224) }\end{array}$ & 98 & \multirow[t]{2}{*}{$\begin{array}{l}\text { Marine sediment above hydrate } \\
\text { ridge }\end{array}$} \\
\hline & & & $\begin{array}{l}\text { Anaeromyxobacter dehalogenans } \\
\text { (AF382396) }\end{array}$ & 89 & \\
\hline \multirow[t]{2}{*}{ Bacteroidetes } & \multirow[t]{2}{*}{$\begin{array}{l}\text { GWS-SE-7 (419), } \\
(\mathrm{AY} 274249)\end{array}$} & \multirow[t]{2}{*}{ May 99} & $\begin{array}{l}\text { Flavobacteriaceae bacterium T15 } \\
\text { (AY177723) }\end{array}$ & 100 & $\begin{array}{l}\text { German Wadden Sea }\left(10^{-5} \text { dilution }\right. \\
\text { culture })\end{array}$ \\
\hline & & & $\begin{array}{l}\text { Tenacibaculum mesophilum } \\
\text { (AB032501) }\end{array}$ & 94 & Marine species \\
\hline
\end{tabular}

\section{Suspended matter, chlorophyll, algae and bacterial numbers}

The wind strength and direction were important in controlling dynamics of suspended matter (SPM, particulate carbon [PC], POC), as shown by the correlation analysis and at events like in November 1999 and February 2000. At these times, the highest concentrations of SPM and PC were recorded at the highest wind strength (February) and a particular situation with even higher resuspension, when the wind blew from the north-northeast over a wide fetch (November) without any protection by the groyne. The peak in bacterial numbers at this time of low chl a concentration and the extremely high value in phaeopigment concentration also point to a resuspension event. These findings of the significance of wind-induced vertical mixing for controlling SPM dynamics in the Wadden Sea are in line with previous observations (Van Leussen 1996, Joordens et al. 2001, McCandliss et al. 2002). Chl a and phaeopigment concentrations were not significantly correlated to wind strength, SPM or POC, which is not surprising because phytoplankton biomass constituted highly variable proportions of POC. This notion reflects the fact that phytoplankton primary production is not the predominant source of organic matter, i.e. substrate for growth of heterotrophic bacteria, and that other sources contribute substantial and variable amounts. 


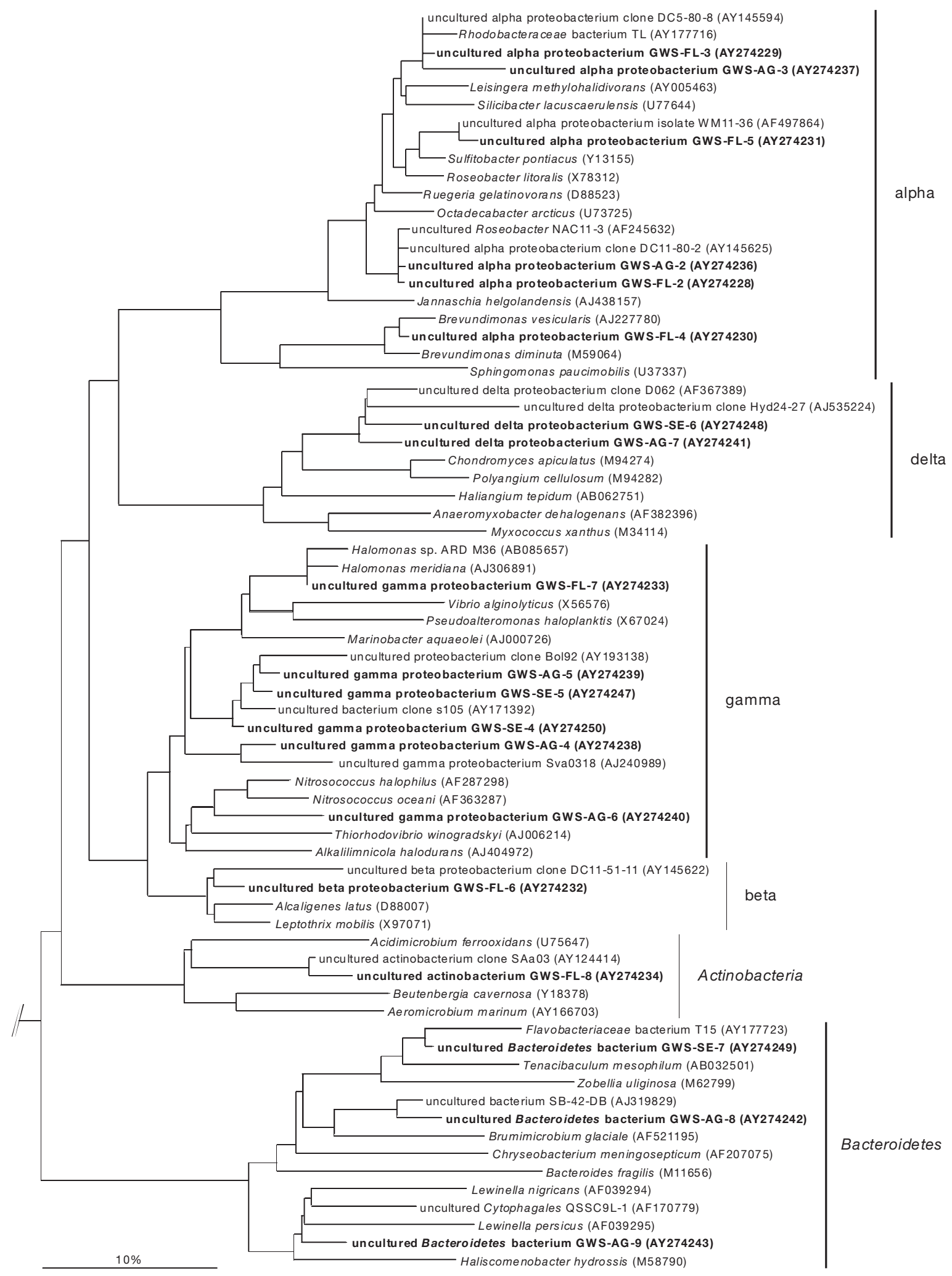

Fig. 7. Maximum-likelihood tree showing the phylogenetic affiliation of the 16S rRNA gene sequences obtained from excised DGGE bands (bold). Different classes of the Proteobacteria are indicated by alpha, beta, gamma and delta. Selected sequences from the Cyanobacteria were used to root the tree. Scale bar indicates $10 \%$ sequence divergence. Accession no. in parentheses 
Bacterial numbers did not show any significant correlation to any parameter for the entire study period, but were significantly correlated to POC during the winter period and to phaeopigments during the summer period, although only on the basis of 4 data points. Similar findings of weak or non-existing correlations were reported from other studies, especially when phytoplankton primary production was not the major substrate source (e.g. Findlay et al. 1991, Poremba et al. 1999c). Our bacterial numbers are well in the range of other studies on the Wadden Sea (Admiraal et al. 1985, Van Duyl \& Kop 1988, Grossart et al. 2004). Poremba et al. (1999b) reported lower numbers from the North Frisian Wadden Sea. Please note that we only assessed total bacterial numbers in the water column and did not differentiate between the free-living and aggregate-associated fractions. Relative proportions of both fractions in the Wadden Sea do vary seasonally with proportions of free-living bacteria of 70 to $85 \%$ in May and equal proportions of both fractions in November (Grossart et al. 2004). Bacterial numbers in Wadden Sea sediments are higher by roughly 3 orders of magnitude than in the water column (Llobet-Brossa et al. 1998, H. Stevens unpubl. data) and document the completely different substrate and growth conditions in these 2 compartments.

One of the major factors controlling bacterial growth dynamics is the input of organic matter. In shallow turbid systems like the Wadden Sea with strong hydrodynamic forcing and light limitation, organic matter is supplied by primary production of phytoplankton but also by benthic microalgae (De Jonge \& van Beusekom 1995, Heip et al. 1995, Tillmann et al. 2000, Jago et al. 2002, De Brouwer et al. 2003). We found a pronounced seasonal variability of the phytoplankton composition. During and after the spring bloom from March to June, when chl a concentrations peaked and PhytoC constituted high proportions of POC, typical planktonic diatoms also found in the German Bight (Guinardia spp., Chaetoceros spp., Rhizosolenia spp., Thalassiosira spp.) were most abundant, suggesting that organic matter input of phytoplankton origin was relatively high during this period. The major forms we identified were typical for the given season and are in line with previous studies from the same area (Niesel \& Günther 1999). The relatively high proportions of benthic algae such as Paralia sulcata, Lithodesmium undulatum and other pennate diatoms in August and September 1999 and from November 1999 to February 2000 indicate that growth of benthic algae and resuspension was important in supplying organic matter to bacteria in the water column during these periods. The high phaeopigment concentrations during winter and in April and June 2000 suggest that not only a supply of fresh organic matter by primary production but also decaying algae were the major source of organic matter during these periods.

\section{Bacterial communities}

To analyse the structure of the bacterial communities we used DGGE of PCR-amplified 16S rRNA gene fragments and cluster analysis. These methods have been widely used but include limitations and biases such as selective PCR amplifications and detection of target sequences constituting only $1 \%$ or more of the extractable rDNA (e.g. Muyzer et al. 1993, Murray et al. 1996, Cottrell \& Kirchman 2000, Fromin et al. 2002). Detection of phylotypes of the Flavobacteria/Sphingobacteria group appeared to be particularly biased. Even though we detected only 3 phylotypes of this group (GWS-AG-8, -AG-9 and -SE-7) (Fig. 5, Table 2), it has been shown by fluorescence in situ hybridisation (FISH) that this group constitutes substantial fractions of all 3 bacterial communities in the Wadden Sea (Llobet-Brossa et al. 1998, Simon et al. 2003). Further, the application of group-specific primers with DGGE analysis detected several and different phylotypes of this group in the free-living and aggregate-associated bacterial communities in the Wadden Sea (Rink et al. 2003). Hence, our results present a selected suite of phylotypes of the 3 bacterial communities, biased against the Flavobacteria/Sphingobacteria group. Because we applied general primers also used in many other DGGE studies, our results are comparable to those studies but nevertheless provide a valuable insight into the composition and temporal dynamics of the bacterial communities in the Wadden Sea.

Cluster analysis is a common method for evaluating DGGE-banding patterns (Hollibaugh et al. 2000, Juck et al. 2000, Van der Gucht et al. 2001, Casamayor et al. 2002), but possible biases with respect to the method of analysis and the quality of the gel documentation cannot be excluded. In accordance with preliminary analyses and on the basis of work done by other authors (Ferrari \& Hollibaugh 1999, Selje \& Simon 2003), we assume that the method we chose to evaluate the cluster analysis yields reliable results. The inclusion of the chloroplast sequences (GWS-FL-1, -AG-1, -SE-1, -SE-2, -SE-3) may have affected our cluster analysis to a certain extent such as the separation of the narrow subcluster of the aggregate-associated bacterial community from December 1999 to April 2000 because Band AG-1 was absent during this time (Fig. 5). The identification of the large clusters of the 3 bacterial communities by cluster analysis, however, was not biased because the general banding patterns of these communities exhibited pronounced differences (Fig. 5). These clusters are separated well below the $93 \%$ level of the Pearson correlation, beyond which branching is not significant (Fig. 6).

The sediment surface-associated bacterial community remained most stable over time, indicating that 
this habitat was least affected by changing environmental and biological conditions. Temporal changes in benthic algal communities, sedimentation and resuspension events were obviously not reflected in pronounced changes in the numbers of detected DGGE bands. Because we used an approach aimed at detecting rDNA but not rRNA using rt-PCR, we cannot rule out the possibility that the relative metabolic activity of the phylotypes changed seasonally. Prominent phylotypes detected throughout the study period were identified as $2 \gamma$-Proteobacteria (GWS-SE-4,-SE-5) and $1 \delta$-Proteobacterium (GWS-SE-6) (Fig. 5, Table 2). Phylotype SE-6 exhibited a sequence similarity of $98 \%$ to a phylotype on aggregates (GWS-AG-7) and to one detected above gas hydrates (Knittel et al. direct submission to GenBank). $\delta$-Proteobacteria have often been found in marine sediments and include sulfatereducing bacteria and the strictly aerobic and chemoorganotrophic Myxobacteria (lizuka et al. 1998, 2003, Llobet-Brossa et al. 1998, 2002, Ravenschlag et al. 1999, Wieringa et al. 2000, Rütters et al. 2002). According to the sequence similarities of the closest relatives, our phylotypes belong to the Myxobacteria, which appear to be consistently present in the surface sediment and on aggregates. We also detected phylotypes of algal chloroplasts and only 1 sediment surface-associated phylotype of the Flavobacteria/Sphingobacteria group, which occurred in May 1999 (GWS-SE-7) (Fig. 5, Table 2). This was identical to the sequence of an isolate from the German Wadden Sea obtained from a $10^{-5}$ dilution culture (Flavobacteriaceae bacterium T15; Brinkhoff et al. 2004). The detection of only 1 phylotype of this group appears surprising because bacteria of this phylogenetic group were found to constitute up to $6 \%$ of total bacteria in surface sediments of the Wadden Sea in December, applying FISH (Llobet-Brossa et al. 1998). We do not think that bacteria of this phylogenetic group, in fact, were of such low significance as our findings imply, but that methodological biases led to this result (see above). The fact that we did not detect any $\alpha$-Proteobacteria among the prominent bands in the surface sediment is in line with low numbers of $\alpha$-Proteobacteria reported by Llobet-Brossa et al. (1998).

The composition of the free-living bacterial community exhibited seasonal changes; however, these were not directly related to any environmental or biological variables we assessed. Certain phylotypes, however, occurred only when particular algae were present such as GWS-FL-4 during a Chaetoceros bloom in March 2000, suggesting that relationships between specific bacteria and algae exist. Tidal dynamics, however, have no effect on the composition of the freeliving bacterial community, except that North Sea water may be introduced at high tide, resulting in lower bacterial numbers (Grossart et al. 2004). The most prominent sequences which occurred throughout most of the study period affiliated with the Roseobacter clade of $\alpha$-Proteobacteria and had sequence similarities of $99 \%$ to sequences retrieved from $10^{-5}$ and $10^{-6}$ dilution cultures of the polyhaline section of the Weser estuary, located east of the Wadden Sea (GWS-FL-2, FL-3; Table 2) (Selje et al. 2005), and to a phylotype from the polyhaline section of the Weser estuary (GWS-FL-5; Table 2) (Selje \& Simon 2003). Phylotype GWS-FL-3 was identical to a recently described isolate, Rhodobacteriaceae bacterium TL (Brinkhoff et al. 2004). As phylotypes GWS-FL-3 and -FL-5 had nearly identical band positions we are unable to decide which one occurred at which time. In the North Sea and the Weser estuary, phylotypes of the Roseobacter clade were reported to be prominent members of the bacterioplankton throughout most of the year, constituting up to $9 \%$ of total bacterial numbers (Eilers et al. 2000, Selje \& Simon 2003, Selje et al. 2004). We identified only $1 \delta$-proteobacterial phylotype (GWS-FL-7) within the free-living bacterial community and only 1 phylotype affiliating with Actinobacteria (GWS-FL-8) and 1 with $\beta$-Proteobacteria (GWS-FL-6); however, these only occurred during certain periods. $\beta$-Proteobacteria are known to be prominent members of freshwater bacterial communities (Glöckner et al. 1999), and only a few phylotypes of this group have been found in brackish and marine waters (Rappé et al. 2000, Selje \& Simon 2003, Selje et al. 2005). Phylotype GWS-FL-6 showed a sequence similarity of $97 \%$ to a phylotype of a $10^{-5}$ dilution culture from the brackish section of the Weser estuary (Selje et al. 2005).

In the aggregate-associated bacterial community, we detected the highest number of bands and pronounced seasonal changes. Interestingly, this community exhibited overlaps with the free-living and sediment surface-associated communities, indicating that exchange processes with and transitions to both other environments existed and/or that several bacteria were able to prosper in more than one of these habitats. One of the 3 most prominent phylotypes of the aggregate-associated community detected throughout the study period (GWS-AG-2, affiliated with the Roseobacter clade) was identical to a prominent member of the free-living bacterial community (GWS-FL-2) and closely related to phylotypes of adjacent water masses (see above). We do not think that this overlap was due to clogging of filters, which would trap free-living bacteria in the aggregate-associated fraction, because cells of this phylotype were also detected on aggregates by a specific FISH probe targeting this phylotype and close relatives (D. Dotschkal unpubl. results). Phylotype GWSAG-7 detected during most of the study period (September 1999 to April 2000, Fig. 5) and affiliated 
with $\delta$-Proteobacteria was $98 \%$ similar to GWS-SE-6, which was consistently present on the sediment surface (see above). Two prominent members of the aggregate-associated bacterial community affiliated with $\gamma$-Proteobacteria (GWS-AG-4, -AG-5). GWS-AG5 showed a $99 \%$ sequence similarity with GWS-SE-5. Phylotypes of $\gamma$-Proteobacteria were only sporadically detected in the free-living bacterial community (see above), but consistently on the sediment surface. Applying FISH, $\gamma$-Proteobacteria were found to be prominent members of the free-living, aggregateassociated and sediment surface-associated bacterial communities in the Wadden Sea (Llobet-Brossa et al. 1998, Simon et al. 2003) and the Weser and Elbe estuaries (Simon et al. 2002, Selje \& Simon 2003). Possible reasons why we did not detect more sequences of $\gamma$ Proteobacteria include the fact that we only picked selected bands for sequencing and a high diversity of $\gamma$-proteobacterial phylotypes (see above). Phylotypes of the Flavobacteria/Sphingobacteria group were only detected on 2 occasions. which presumably underestimates the significance of this phylogenetic group on aggregates for reasons discussed above.

\section{CONCLUSIONS}

Our study complements investigations from other systems, which also showed that several bacteria and bacterial groups are basic constituents of the bacterial communities but that some members only occur during certain or colder periods (Höfle et al. 1999, Glöckner et al. 2000, Pinhassi \& Hagström 2000, Eilers et al. 2001, Zwisler et al. 2003). Prominent members occurred over most of or during the entire study period, indicating that the basic structure of each community prevailed despite the strong hydrodynamic forcing and intense exchange processes between the dissolved and particulate phase and the sediment, and with the adjacent land and sea. The composition of these communities was not directly related to seasonal dynamics in suspended matter and phytoplankton properties, even though some variations did occur seasonally. In the aggregate-associated community we detected the highest number of bands, and overlaps to the other communities existed, indicating its mediating role for bacterial processes in the water column and the sediment surface.

Acknowledgements. We would like to thank C.-D. Duerselen for an introduction to and data interpretation of algal taxonomy, M. Lunau for valuable discussions on data of suspended matter constituents, and A. Schlingloff, H. P. Grossart, and B. Kuerzel for assistance in field work. We are grateful to 3 anonymous referees for constructive suggestions on an earlier version of this manuscript. This work was supported by grants from the Volkswagen Foundation within the Lower Saxonian priority program Marine Biotechnology, and from the Deutsche Forschungsgemeinschaft within the Research Group FG-432 'BioGeoChemistry of the Wadden Sea'.

\section{LITERATURE CITED}

Admiraal W, Bouwman LA, Hoekstra L, Romeyn K (1983) Qualitative and quantitative interactions between microphytobenthos and herbivorous meiofauna on a brackish intertidal mudflat. Int Rev Gesamten Hydrobiol 68: 175-191

Admiraal W, Beukema J, Vanes FB (1985) Seasonal fluctuations in the biomass and metabolic activity of bacterioplankton and phytoplankton in a well-mixed estuary-the Ems-Dollard (Wadden Sea). J Plankton Res 7:877-890

Babu CP, Brumsack HJ, Schnetger B (1999) Distribution of organic carbon in surface sediments along the eastern Arabian Sea: a revisit. Mar Geol 162:91-103

Behrends B, Liebezeit G (1999) Particulate amino acids in Wadden Sea waters-seasonal and tidal variations. J Sea Res 41:141-148

Böttcher ME, Hespenheide B, Llobet-Brossa E, Beardsley C and 6 others (2000) The biogeochemistry, stable isotope geochemistry, and microbial community structure of a temperate intertidal mudflat: an integrated study. Cont Shelf Res 20:1749-1769

Brinkhoff T, Muyzer G (1997) Increased species diversity and extended habitat range of sulfur-oxidizing Thiomicrospira spp. Appl Environ Microbiol 63:3789-3796

Brinkhoff T, Bach G, Heidorn T, Liang L, Schlingloff A, Simon M (2004) Antibiotic production by a Roseobacter clade affiliated species from the German Wadden Sea and its antagonistic effects on indigenous isolates. Appl Environ Microbiol 70:2560-2565

Casamayor EO, Massana R, Benlloch S, Ovreas L and 6 others (2002) Changes in archaeal, bacterial and eukaryal assemblages along a salinity gradient by comparison of genetic fingerprinting methods in a multipond solar saltern. Environ Microbiol 4:338-348

Cottrell MT, Kirchman DL (2000) Community composition of marine bacterioplankton determined by $16 \mathrm{~S}$ rRNA gene clone libraries and fluorescence in situ hybridization. Appl Environ Microbiol 66:5116-5122

Crump BC, Baross JA, Simenstad CA (1998) Dominance of particle-attached bacteria in the Columbia River estuary, USA. Aquat Microb Ecol 14:7-18

De Brouwer JFC, de Deckere EMGT, Stal LJ (2003) Distribution of extracellular carbohydrates in three intertidal mudflats in Western Europe. Estuar Coast Shelf Sci 56:313-324

De Jonge VN, van Beusekom JEE (1995) Wind- and tideinduced respuspension of sediment and microphytobenthos from tidal flats in the Ems estuary. Limnol Oceanogr 40:766-778

Don RH, Cox PT, Wainwright BJ, Baker K, Mattick JS (1991) 'Touchdown' PCR to circumvent spurious priming during gene amplification. Nucleic Acids Res 19:4008

Drebes G (1974) Marine phytoplankton. Georg Thieme, Stuttgart

Eilers H, Pernthaler J, Glöckner FO, Amann R (2000) Culturability and in situ abundance of pelagic bacteria from the North Sea. Appl Environ Microbiol 66:3044-3051

Eilers H, Pernthaler J, Peplies J, Glöckner FO, Gerdts G, Amann R (2001) Isolation of novel pelagic bacteria from the German Bight and their seasonal contributions to surface picoplankton. Appl Environ Microbiol 67:5134-5142 
Ferrari VC, Hollibaugh JT (1999) Distribution of microbial assemblages in the Central Arctic Ocean Basin studied by PCR/DGGE: analysis of a large data set. Hydrobiologia 401:55-68

Findlay SF, Pace ML, Lints D, Cole JJ, Caraco NF, Peierls B (1991) Weak coupling of bacterial and algal production in a heterotrophic system: the Hudson River estuary. Limnol Oceanogr 36:268-278

Fromin N, Hamelin J, Tarnawski S, Roesti D and 6 others (2002) Statistical analysis of denaturing gel electrophoresis (DGE) fingerprinting patterns. Environ Microbiol 4:634-643

Garrity GM, Winters M, Searles DB (2001) Taxonomic outline of the procaryotic genera. In: Garrity GM (ed) Bergey's manual of systematic bacteriology. Springer, New York, p 1-39

Glöckner FO, Fuchs BM, Amann R (1999) Bacterioplankton compositions of lakes and oceans: a first comparison based on fluorescence in situ hybridization. Appl Environ Microbiol 65:3721-3726

Glöckner FO, Zaichikov E, Belkova N, Denissova L, Pernthaler J, Pernthaler A, Amann R (2000) Comparative 16S rRNA analysis of lake bacterioplankton reveals globally distributed phylogenetic clusters including an abundant group of actinobacteria. Appl Environ Microbiol 66: 5053-5065

Grossart HP, Brinkhoff T, Martens T, Duerselen C, Liebezeit, Simon M (2004) Tidal dynamics of dissolved and particulate matter and bacteria in the German Wadden Sea in spring and fall. Limnol Oceanogr 49:2212-2222

Heip CHR, Goosen NK, Herman PMJ, Kromkamp J, Middleburg JJ, Soetart K (1995) Production and consumption of biological particles in temperate tidal estuaries. Oceanogr Mar Biol Annu Rev 33:1-149

Höfle MG, Haas H, Dominik K (1999) Seasonal dynamics of bacterioplankton community structure in a eutrophic lake as determined by 5S rRNA analysis. Appl Environ Microbiol 65:3164-3174

Hollibaugh JT, Wong PS, Murrell MC (2000) Similarity of particle-associated and free-living bacterial communities in the northern San Francisco Bay, California. Aquat Microb Ecol 21:245-256

Iizuka T, Jojima Y, Fudou R, Yamanaka S (1998) Isolation of myxobacteria from the marine environment. FEMS Microbiol Lett 169:317-322

Iizuka T, Jojima Y, Fudou R, Tokura M, Hiraishi A, Yamanaka S (2003) Enhygromyxa salina gen. nov., sp nov., a slightly halophilic myxobacterium isolated from the coastal areas of Japan. Syst Appl Microbiol 26:189-196

Jago CF, Jones SE, Latter RJ, McCandliss RR, Hearn MR, Howarth MJ (2002) Resuspension of benthic fluff by tidal currents in deep stratified waters, northern North Sea. J Sea Res 48:259-269

Joordens JCA, Souza AJ, Visser A (2001) The influence of tidal straining and wind on suspended matter and phytoplankton distribution in the Rhine outflow region. Cont Shelf Res 21:301-325

Juck D, Charles T, Whyte LG, Greer CW (2000) Polyphasic microbial community analysis of petroleum hydrocarboncontaminated soils from two northern Canadian communities. FEMS Microbiol Ecol 33:241-249

Llobet-Brossa E, Rossello-Mora R, Amann R (1998) Microbial community composition of Wadden Sea sediments as revealed by fluorescence in situ hybridization. Appl Environ Microbiol 64:2691-2696

Llobet-Brossa E, Rabus R, Bottcher ME, Konneke M and 6 others (2002) Community structure and activity of sulfatereducing bacteria in an intertidal surface sediment: a multi-method approach. Aquat Microb Ecol 29:211-226
Ludwig W, Strunk O, Westram R, Richter L and 28 others (2004) ARB: a software environment for sequence data. Nucleic Acid Res 32:1363-1371

Lunau M, Rink B, Grossart HP, Simon M (2003) How to sample marine microaggregates in shallow and turbid environments? Problems and solutions. Ber Forschungszentrum Terramare 12:85-88

MacGregor BJ, Moser DP, Alm EW, Nealson KH, Stahl D (1997) Crenarchaeota in Lake Michigan sediment. Appl Environ Microbiol 63:1178-1181

McCandliss RR, Jones SE, Hearn M, Latter R, Jago CF (2002) Dynamics of suspended particles in coastal waters (southern North Sea) during a spring bloom. J Sea Res 47: 285-302

Messing J (1983) New M13 vectors for cloning. Methods Enzymol 101:20-78

Milligan TG (1995) An examination of the settling behaviour of a flocculated suspension. Neth J Sea Res 33:163-171

Murray AE, Hollibaugh JT, Orrego C (1996) Phylogenetic compositions of bacterioplankton from two California estuaries compared by denaturing gradient gel electrophoresis of 16S rDNA fragments Appl Environ Microbiol 62:2676-2680

Muyzer G, de Waal EC, Uitterlinden AG (1993) Profiling of complex microbial populations by denaturing gradient gel electrophoresis analysis of polymerase chain reactionamplified genes coding for 16S rRNA. Appl Environ Microbiol 59:695-700

Muyzer G, Brinkhoff T, Nübel U, Santegoeds C, Schäfer H, Wawer C (1998) Denaturing gradient gel electrophoresis (DGGE) in microbial ecology. In: Akkermans ADL, van Elsas JD, Bruijn, FJ (eds) Molecular microbial ecology manual. Kluwer Academic Publishers, Dordrecht, p 1-27

Niesel V, Günther CP (1999) Distribution of nutrients, algae and zooplankton in the Spiekeroog Backbarrier System. In: Dittmann S (ed) The Wadden Sea ecosystem: stability, properties and mechanisms. Springer, Berlin, p 77-93

Parsons TR, Maita Y, Lalli CM (1984) A manual of chemical and biological methods for seawater analysis. Pergamon Press, New York, p 101-112

Pinhassi J, Hagström ^ (2000) Seasonal succession in marine bacterioplankton. Aquat Microb Ecol 21:245-256

Poremba K, Durselen CD, Stoeck T (1999a) Succession of bacterial abundance, activity and temperature adaptation during winter 1996 in parts of the German Wadden Sea and adjacent coastal waters. J Sea Res 42:1-10

Poremba K, Tillmann U, Hesse KJ (1999b) Distribution patterns of bacterioplankton and chlorophyll- $a$ in the German Wadden Sea. Helgol Mar Res 53:28-35

Poremba K, Tillmann U, Hesse KJ (1999c) Tidal impact on planktonic primary and bacterial production in the German Wadden Sea. Helgol Mar Res 53:19-27

Porter KG, Feig YS (1980) The use of DAPI for identifying and counting aquatic microflora. Limnol Oceanogr 25:943-948

Rappé MS, Vergin K, Giovannoni SJ (2000) Phylogenetic comparisons of a coastal bacterioplankton community with its counterparts in open ocean and freshwater systems. FEMS Microbiol Ecol 33:219-232

Ravenschlag K, Sahm K, Pernthaler J, Amann R (1999) High bacterial diversity in permanently cold marine sediments. Appl Environ Microbiol 65:3982-3989

Rink B, Lunau M, Seeberger S, Stevens H, Brinkhoff $T$, Grossart HP, Simon M (2003) Diversity patterns of aggregate-associated and free-living bacterial communities in the German Wadden Sea. Ber Forschungszentrum Terramare 12:96-98

Rütters H, Sass H, Cypionka H, Rullkötter J (2002) Microbial 
communities in a Wadden Sea sediment core - clues from analyses of intact glyceride lipids, and released fatty acids. Org Geochem 33:803-816

Sambrook J, Fritsch EF, Maniatis T (1989) Northern hybridisation. Molecular cloning: a laboratory manual, 2nd edn. Cold Spring Harbour Laboratory Press, New York

Selje N, Simon M (2003) Composition and dynamics of particle-associated and free-living bacterial communities in the Weser estuary, Germany. Aquat Microb Ecol 30:221-237

Selje N, Simon M, Brinkhoff T (2004) A newly discovered Roseobacter cluster in temperate and polar oceans. Nature 427:445-448

Selje N, Brinkhoff T, Simon M (2005) Detection of abundant bacteria in the Weser estuary by culture-dependent and culture-independent approaches. Aquat Microb Ecol (in press)

Simon M, Grossart HP, Schweitzer B, Plough H (2002) Microbial ecology of organic aggregates in aquatic ecosystems. Aquat Microb Ecol 28:175-211

Simon M, Lunau M, Brinkhoff T, Stevens T, Rink B, Duerselen C, Grossart HP (2003) Tidal and seasonal variations in dynamics of microaggregates and associated bacterial communities in the German Wadden Sea. Ber Forschungszentrum Terramare 12:105-108

Stahl DA, Flesher B, Mansfield HR, Montgomery L (1988) Use of phylogenetically based hybridization probes for studies of ruminal microbial ecology. Appl Environ Microbiol 54: 1079-1084

Tillmann U, Hesse KJ, Colijn F (2000) Planktonic primary production in the German Wadden Sea. J Plankton Res 22: 1253-1276

Utermöhl H (1958) Zur Vervollkommnung der quantitativen

Editorial responsibility: Gerhard Herndl,

Den Burg, Texel, The Netherlands
Phytoplanktonmethodik. Mitt Int Verh Theor Angew Limnol 9:1-38

Van der Gucht K, Sabbe K, De Meester L, Vloemans N, Zwart G, Gillis M, Vyverman W (2001) Contrasting bacterioplankton community composition and seasonal dynamics in two neighbouring hypertrophic freshwater lakes. Environ Microbiol 3:680-690

Van Duyl FC, Kop AJ (1988) Temporal and lateral fluctuations in production and biomass of bacterioplankton in the western Dutch Wadden Sea. Neth J Sea Res 22:51-68

Van Leussen W (1996) Erosion/sedimentation cycles in the Ems estuary. Arch Hydrobiol Spec Iss Adv Limnol 47: 179-193

Wainright SC (1990) Sediment-to-water fluxes of particulate material and microbes by resuspension and their contribution to the planktonic food web. Mar Ecol Prog Ser 62: 271-281

Wainright SC (1997) Stimulation of heterotrophic microplankton production by resuspended marine sediments. Science 238:1710-1712

Wieringa EBA, Overmann J, Cypionka H (2000) Detection of abundant sulfate-reducing bacteria in marine oxic sediment layers by a combined cultivation and molecular approach. Environ Microbiol 2:417-427

Wolfstein K, Colijn F, Doerffer R (2000) Seasonal dynamics of microphytobenthos biomass and photosynthetic characteristics in the northern German Wadden Sea, obtained by the photosynthetic light dispensation system. Estuar Coast Shelf Sci 51:651-662

Zwisler W, Selje N, Simon M (2003) Seasonal patterns of the bacterioplankton community composition in a large mesotrophic lake. Aquat Microb Ecol 31:211-225

Submitted: July 16, 2004; Accepted: November 17, 2004

Proofs received from author: December 17, 2004 